\title{
Rock glaciers in Daxue Shan, south-eastern Tibetan Plateau: an inventory, their distribution, and their environmental controls
}

\section{Zeze Ran and Gengnian Liu}

Key Laboratory for Earth Surface Processes of the Ministry of Education, College of Urban and Environmental Sciences, Peking University, Beijing, 100871 China

Correspondence: Zeze Ran (ranzeze@pku.edu.cn)

Received: 31 December 2017 - Discussion started: 23 January 2018

Revised: 2 July 2018 - Accepted: 3 July 2018 - Published: 16 July 2018

\begin{abstract}
Rock glaciers are typical periglacial landforms. They can indicate the existence of permafrost, and can also shed light on the regional geomorphological and climatic conditions under which they may have developed. This article provides the first rock glacier inventory of Daxue Shan, south-eastern Tibetan Plateau. The inventory is based on analyses of Google Earth imagery. In total, 295 rock glaciers were identified in Daxue Shan, covering a total area of $55.70 \mathrm{~km}^{2}$ between the altitudes of 4300 and $4600 \mathrm{~m}$ above sea level. Supported by ArcGIS and SPSS software programmes, we extracted and calculated morphometric parameters of these rock glaciers, and analysed the characteristics of their spatial distribution within Daxue Shan. Our inventory suggests that the lower altitudinal boundary for permafrost across the eight aspects of observed slopes differs significantly and that the lower altitudinal permafrost boundary is $\sim 104 \mathrm{~m}$ higher on western than eastern-facing slopes. Moraine-type and talus-derived rock glaciers exhibit mean gradients that are all concentrated within the $22-35^{\circ}$ range. However, lobate rock glaciers $\left(27-45^{\circ}\right)$ have a higher mean gradient than tongue-shaped rock glaciers $\left(22-35^{\circ}\right)$. Shady (i.e. N, NE, and E) slopes appear related to the presence of moraine-type rock glaciers, whereas sunny (i.e. W, SW, and S) slopes appear related to the presence of talus-derived rock glaciers. Rock glaciers in Daxue Shan are more concentrated within tertiary monzonitic granite, which is more sensitive than other lithological components to the freeze-thaw process. Continuous weathering of this substrate provides the ideal raw material for the rock glacier development. These results show that environmental controls (i.e. topographical, climatic, lithological factors) greatly affect the formation and development of rock glaciers. This study provides important
\end{abstract}

data for exploring the relation between maritime periglacial environments and the development of rock glaciers on the south-eastern Tibetan Plateau (TP). It may also highlight the characteristics typical of rock glaciers found in a maritime setting.

\section{Introduction}

The term "rock glacier" was first proposed by the American scholar Capps (1910) when investigating Kennicott Glacier in Alaska. By definition, rock glaciers consist of perennially frozen masses of ice and debris that creep downslope under the weight of gravity (Haeberli, 1985; Barsch, 1996; Haeberli et al., 2006). As many Himalayan rock glaciers develop out of moraines, it is hard to distinguish where the moraine ends and the rock glacier begins. The bodies of rock glaciers are similar to moraines in that, as their ice mass moves over a pore ice surface, they do not sort materials in relation to the thickness of the debris they contain. Statistically, rock glaciers occupy extensive areas above the tree line in the mountainous regions of the world (Haeberli, 1985). Indeed, there are $\sim 73000$ rock glaciers globally (Jones et al., 2018a), with $\sim 1000$ active rock glaciers in the Swiss Alps alone. The freeze-thaw process experienced by the ice masses within rock glaciers can exert a major impact on the hydrological cycle (Azócar and Brenning, 2010; Jones et al., 2018a, b), and creep of rock glaciers can significantly negatively influence any infrastructure built on top. Rock glacier research may therefore aid a more detailed and accurate understanding of the genesis of periglacial geomorphology and 
of the relations between rock glaciers and their local environments.

Over the last 20 years, with the rapid development of more advanced Geographical Information Systems (GIS), remote sensing (RS), and statistical techniques, rock glacier research has entered a new, accelerated phase. This phase has included compilations of rock glacier inventories (e.g. Bolch and Marchenko, 2009; Cremonese et al., 2011; Bolch and Gorbunov, 2014; Falaschi et al., 2014; Colucci et al., 2016; Janke et al., 2017; Wang et al., 2017b; Jones et al., 2018a), mapping of their spatial distributions and their relations with environmental controls such as topography and climate (e.g. Chueca, 1992; Brazier et al., 1998; Brenning, 2005; Janke, 2007; Johnson et al., 2007; Kenner and Magnusson, 2017; Onaca et al., 2017; Jones et al., 2018b), estimations of the distribution of permafrost based on rock glaciers (e.g. Allen et al., 2008; Boeckli et al., 2012; Schmid et al., 2015; Sattler et al., 2016), and investigations of rock glacier dynamics (e.g. Haeberli et al., 2006; Liu et al., 2013; Müller et al., 2016; Wang et al., 2017b). However, compared with ice glaciers, rock glaciers remain poorly described and infrequently studied. One reason is because they are mixtures of rock fragments of different sizes, are spectrally similar to their surroundings, and therefore cannot easily be automatically mapped from optical RS data (Brenning, 2009). In addition, both supraglacial debris (on the glacier) and debris along the glacier margins originate from surrounding valley rock (Jones et al., 2018b); thus their debris surfaces do not produce distinct spectral signals. As a result, it is often difficult to distinguish relict rock glaciers from inactive rock glaciers that still contain ice using optical RS imagery (Millar and Westfall, 2008; Kenner and Magnusson, 2017).

Rock glacier research in China has, up to this point, focused principally on the Tian Shan Mountains (Cui and Zhu, 1989; Qiu, 1993; Zhu et al., 1996; Wang et al., 2017b), rather than on the rock glaciers of Daxue Shan on the south-eastern margins of the TP. This region has been, and continues to be, strongly uplifted and deformed due to the extrusion and collision of the Indian and Eurasian continental plates since the beginning of the Quaternary, and is therefore characterized by an extremely complex matrix of relations between different environmental factors such as climate and geomorphology. It is therefore of particular importance to study the environmental controls on the rock glaciers here to better understand the complex geographical environment, identify potential natural hazards, and aid environmental planning and management. The purpose of this study was twofold: first, to describe and complete a systematic inventory of the previously undocumented rock glaciers in Daxue Shan; and second, to characterize their distribution and environmental controls (i.e. climatic, topographical, and lithological factors). Stemming from these goals, there is an analysis and discussion of the mechanisms driving the formation, development, and spatial distribution of the rock glaciers in relation to different environmental controls in this maritime setting.

\section{Study area}

The study area is situated in China's Sichuan Province between $29.956-30.573^{\circ} \mathrm{N}$ and $101.477-101.974^{\circ} \mathrm{E}$ (Fig. 1). To the west is the uplifted eastern sector of the TP, and to the east are mountain gorges, both of which are important geographical boundaries (Zhang et al., 2017). The topography of Daxue Shan is characterized by the strong downcutting of high-energy water courses, resulting in a great altitudinal range (1349-7321 ma.s.1.). The region's climate is relatively warm and humid, and is strongly influenced by a south-westerly monsoonal atmospheric circulation (Wang et al., 2017a). East of Daxue Shan is a subtropical monsoon climatic zone which is principally affected by the aforementioned south-westerly monsoonal atmospheric circulation but also by a south-easterly monsoonal atmospheric circulation, both of which transport abundant precipitation to this region. West of Daxue Shan the subtropical monsoon and continental plateau climatic zones intersect, producing a coldtemperate climate as well as abundant precipitation. Geologically, Daxue Shan is located where the Songpan, Chuandian, and South China tectonic blocks intersect, with the Xianshuihe (Ganzi-Yushu) Fault passing to the north-west of the region (Zhang, 2013).

\section{Methods}

\subsection{Rock glacier inventory, classification, and database}

The availability of more powerful RS tools such as Google Earth has transformed geomorphological fieldwork and has, on the whole, made the recognition of landforms in remote and poorly accessible areas both fast and easy (Slaymaker, 2001; Bolch, 2004; Kääb et al., 2005). This is beneficial to the present study as Daxue Shan is remote and difficult to access; therefore we compiled an inventory of the rock glaciers in this region using high-resolution Google Earth satellite imagery (for the period October 2014-January 2017). Google Earth contains the best freely available imagery for detecting rock glaciers across large spatial areas, and it has been previously used for rock glacier identification in the Bolivian Andes (Rangecroft et al., 2014) and the Hindu Kush Himalayan region (Schmid et al., 2015).

Rock glaciers are characterized by distinct flow features and structural patterns. Transversal or longitudinal flow features (ridges and furrows) are common on rock glaciers due to the deformation of their internal ice structures (Clark et al., 1998; Humlum, 2000; Haeberli et al., 2006; Berthling, 2011). Many rock glaciers also exhibit structural patterns such as steep frontal slopes and side slopes with swollen bodies. Due to the constant supply of talus or debris, the surface textures of rock glaciers are usually different from those of the surrounding slopes. Depending on their mobility and permafrost presence, rock glaciers are usually divided 


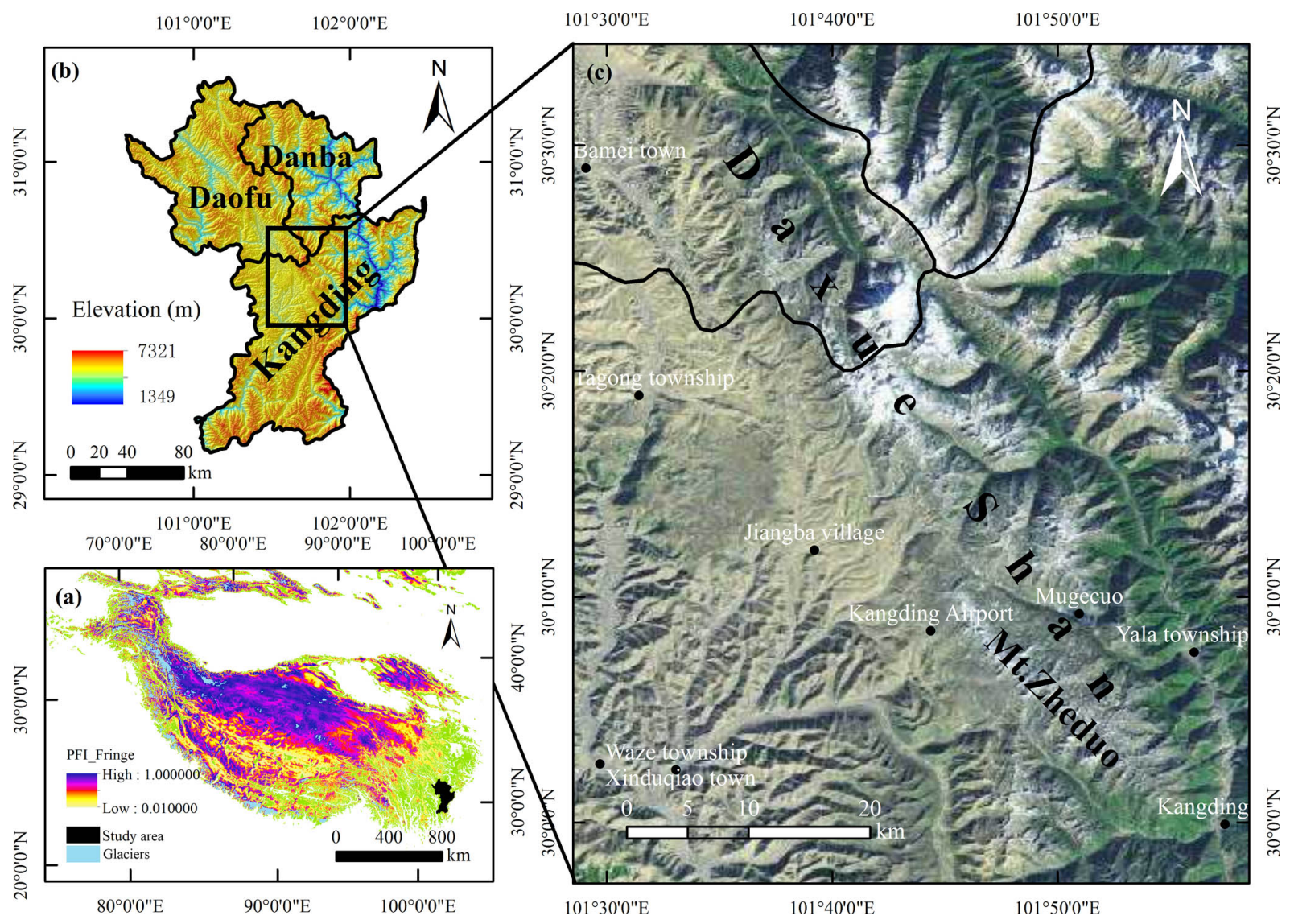

Figure 1. (a) The location of the study area in the permafrost zone of the TP. The Permafrost Zonation Index (PZI) or a corresponding map colour indicates to what degree permafrost exists only under the most favourable conditions (yellow) or nearly everywhere (blue); the map was produced using a temporal resolution of $30 \operatorname{arcsec}(<1 \mathrm{~km})$ on a WGS84 lat-long grid plotted in a projected coordinate system (Gruber, 2012). (b) The geographical and topographical maps of the study area based on a spatial resolution of $30 \mathrm{~m}$ using ASTER GDEM V2 software, as shown in the WGS84 coordinate system. (c) Image of the study area. Map data: Google, Landsat/Copernicus.

into active, inactive, and relict types (Sattler et al., 2016). In general, the presence of ice within active and inactive rock glaciers is indicated by a steep $\left(>35^{\circ}\right)$ frontal slope (Ikeda and Matsuoka, 2002), a well-developed flow-like morphology defined by sets of parallel and curved ridges separated by long v-shaped furrows (Barsch, 1996; Roer and Nyenhuis, 2007), and an absence or sparse occurrence of vegetation (Onaca et al., 2013). Inactive rock glaciers also contain ice but are immobile. In contrast, relict rock glaciers, characterised by surface collapse features as a result of permafrost degradation, have gentler frontal and marginal slopes and are often vegetated (Wahrhaftig and Cox, 1959; Haeberli, 1985; Scotti et al., 2013). Based on these criteria, we visually examined the Google Earth images and identified any potential rock glaciers. We then mapped the rock glaciers in the study region, using the Advanced Spaceborne Thermal Emission and Reflection Radiometer (ASTER) Global Digital Elevation Model version 2 (GDEM V2) data set (to within a horizontal accuracy of $30 \mathrm{~m}$ ) and the Google Earth imagery as guides, marking the geographical location of each identified rock glacier and delineating its outline.

The topographical characteristics of the rock glaciers identified in the inventory were extracted from the GDEM V2 data set and attributed to each rock glacier in a GIS environment. These characteristics were both qualitative and quantitative and included each rock glacier's geographical location (i.e. the coordinates of its centre), type as determined using dynamic, genetic, and geometric criteria (morainetalus; tongue-lobate), aspect, mean gradient of slope $\left(^{\circ}\right)$, area $\left(\mathrm{km}^{2}\right)$, centerline length $(\mathrm{m})$, average width $(\mathrm{m})$, and average altitude (ma.s.l.). A geological layer (Li et al., 1999) was added to the GIS so that the relevant class of bedrock could be attributed to each rock glacier.

Based on the main source of the mass input of debris into each rock glacier and its subsequent transport downslope, we subdivided rock glaciers into two distinct categories: talus-derived rock glaciers developing below talus slopes and moraine-type rock glaciers evolving mainly from glaciogenic materials (Lilleøren and Etzelmüller, 2016; Onaca et 

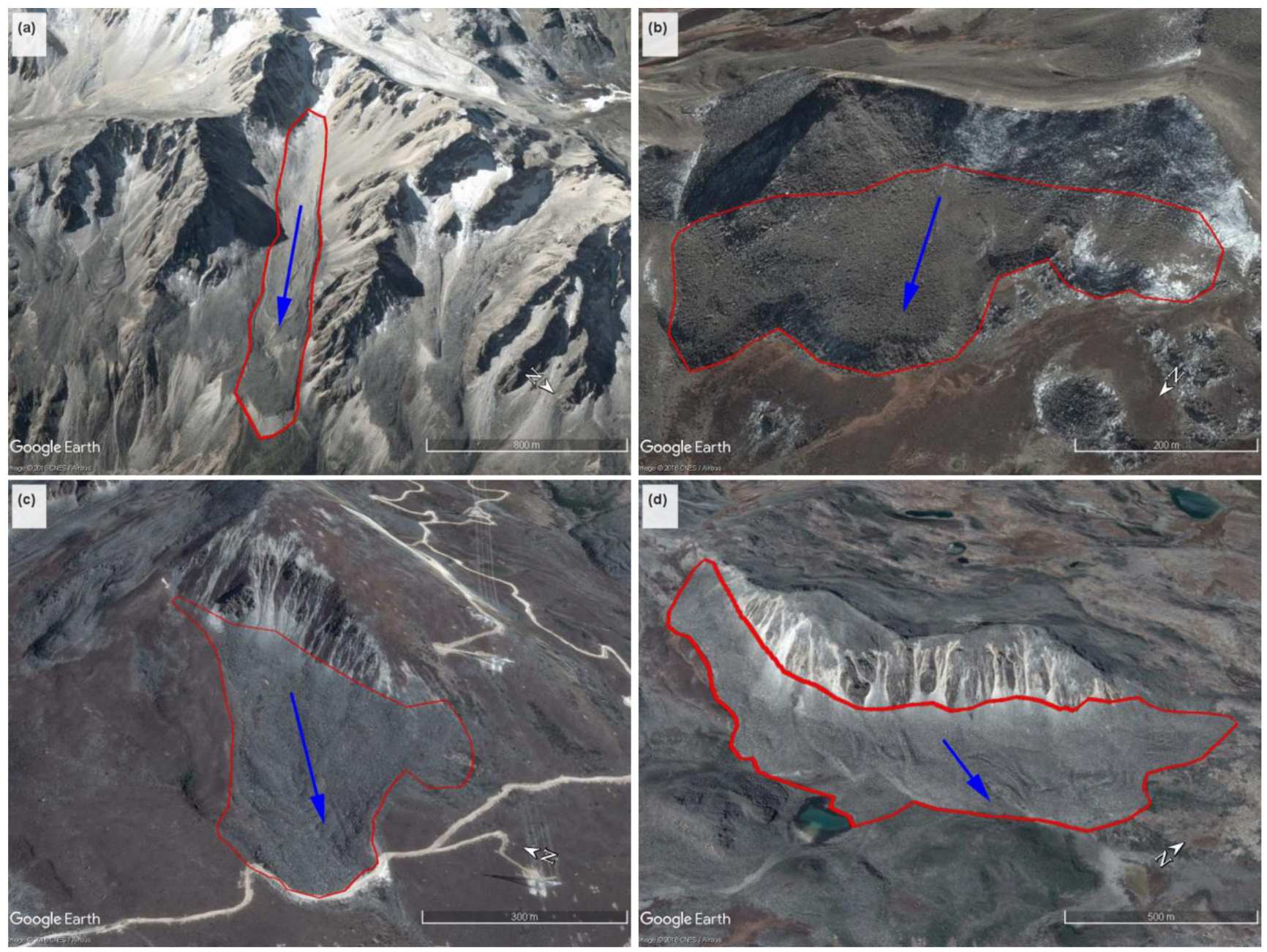

Figure 2. Example images of different types of rock glaciers in Daxue Shan: (a) moraine-type and tongue-shaped rock glaciers $\left(30.332767^{\circ} \mathrm{N}, 101.707756^{\circ} \mathrm{E}\right)(30$ January 2017$)$, (b) moraine-type and lobate rock glaciers $\left(30.217147^{\circ} \mathrm{N}, 101.791585^{\circ} \mathrm{E}\right)\left(15 \mathrm{Novem}^{-}\right.$ ber 2015), (c) talus-derived and tongue-shaped rock glaciers $\left(30.067066^{\circ} \mathrm{N}, 101.819432^{\circ} \mathrm{E}\right)(21$ October 2014$)$, and (d) talus-derived and lobate rock glaciers $\left(30.127825^{\circ} \mathrm{N}, 101.812158^{\circ} \mathrm{E}\right)(21$ October 2014$)$. The red lines show the outlines of the rock glaciers; the blue arrows indicate the direction of flow of the rock glaciers. Map data: Google, CNES/Airbus.

al., 2017) (Fig. 2). In terms of their planar geometry, the length / width ratio was used to distinguish between lobate(length / width ratio < 1) and tongue-shaped (length / width ratio $>1$ ) rock glaciers (Fig. 2) (Giardino and Vick, 1987; Martin, 1987; Barsch, 1996; Guglielmin and Smiraglia, 1998; Onaca et al., 2017). The overall aspect of each rock glacier was manually derived according to the main direction of flow. For spatial analysis, these aspects were then recoded into 8 orientation classes.

However, due to the lack of data regarding the flow behaviour of rock glaciers, it remains to be determined whether these landforms are currently active, or whether they represent inactive rock glaciers. In addition, some aspects of digitisation were challenging based on a visual interpretation of remotely sensed imagery alone and thus the mapped rock glaciers are inherently associated with some spatial un- certainty (Sattler et al., 2016; Jones et al., 2018b). Consequently, some rock glaciers may not be correctly delineated as delimitation of the upper boundary of rock glaciers through geomorphic mapping is arbitrary (Krainer and Ribis, 2012), and delineation of individual polygons where multiple rock glaciers coalesce into a single body is inherently subjective (Scotti et al., 2013; Schmid et al., 2015). Moreover, several complex landforms delineated as rock glaciers may be landslide deposits or relict rock glaciers. Therefore, future research may benefit from integration of additional data sources and further in situ observations that could be used to constrain methods for rock glacier identification using remote sensing and digital elevation data. Further, use of a higher-resolution DEM paired with in situ climate data sets would likely produce a more accurate representation of the distribution of the rock glaciers in Daxue Shan. Due to the 

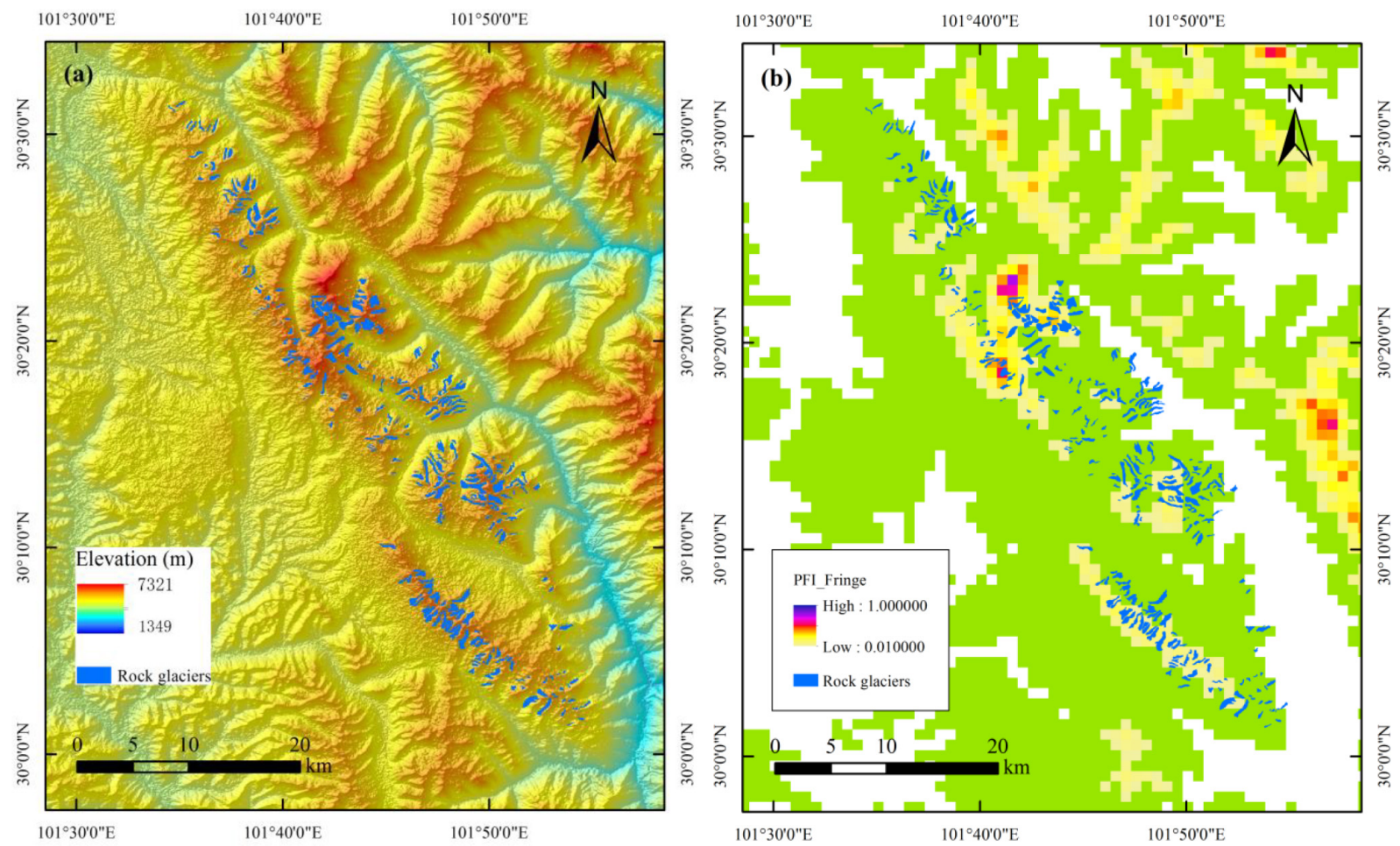

Figure 3. Spatial distribution of rock glaciers vs. (a) elevation (ASTER GDEM V2) and (b) Gruber's (2012) Permafrost Zonation Index (PZI) in Daxue Shan. The green area represents the fringe of uncertainty.

Table 1. KMO and Bartlett's test.

\begin{tabular}{llr}
\hline Kaiser-Meyer-Olkin measure of sampling adequacy & 0.387 \\
\hline Bartlett's test of sphericity & Approx. $\chi^{2}$ & 1216.315 \\
& df & 28 \\
& Sig. & 0.000 \\
\hline
\end{tabular}

Note: $\mathrm{df}$ is degree of freedom, and Sig. is significant level.

limitations imposed by the $30 \mathrm{~m}$ spatial resolution and the uncertainties inherent in any visual identification, we may have failed to identify all the rock glaciers in the study area. As a result of these uncertainties, we chose to examine ranges of values during our statistical analyses.

\subsection{Spatial and statistical analyses}

When there is collinearity between the variables, principal component analysis (PCA) can used to determine the relationships between them (White and Copland, 2015; Ran, 2017). However, in this study, we performed the KaiserMayer-Olkin (KMO) and Bartlett's tests to examine the suitability of the data for factor analysis and we found a KMO value of 0.387 (Table 1), which indicates that the original variables are not suitable for PCA because there is weak collinearity $(\mathrm{KMO}<0.5)$ between them. Therefore, we retained the original variable information, which allows for convenient interpretation and calculation (not too many dimensions), without dimensionality reduction.

We assigned the eight geographical and topographical variables (i.e. latitude, longitude, rock glacier area, length, width, altitude, mean gradient, and aspect) for each of the rock glaciers to an eight-dimensional random variable (i.e. $\left.X_{1}, X_{2}, X_{3} \ldots X_{8}\right)$. A correlation coefficient $\rho_{i j}(i, j=1,2$ $\ldots 8)$ of $X_{i}$ and $X_{j}$ was introduced into the correlation matrix of the random dimensional vector as an 8-order matrix for each element and was denoted by $\mathbf{R}$ :

$\mathbf{R}=\left[\begin{array}{cccc}\rho_{11} & \rho_{12} & \cdots & \rho_{18} \\ \rho_{21} & \rho_{22} & \cdots & \rho_{28} \\ \vdots & \vdots & \vdots & \vdots \\ \rho_{81} & \rho_{82} & \cdots & \rho_{88}\end{array}\right]$

$\rho_{i j}=\frac{\operatorname{cov}\left(X_{i}, X_{j}\right)}{\sqrt{D X_{i}} \sqrt{D X_{j}}}$,

$\operatorname{cov}\left(X_{i}, X_{j}\right)=E\left(\left(X_{i}-E\left(X_{i}\right)\right) \cdot\left(X_{j}-E\left(X_{j}\right)\right)\right)$

The diagonal element of the correlation matrix was 1 , and the correlation matrix itself was symmetrical. We performed the statistical analysis using SPSS $20^{\circledR}$ software. Correlations between the topographical variables were then evaluated using Pearson correlation coefficients at a corresponding 0.05 level of significance. 
Table 2. Statistics for the 295 rock glaciers found in Daxue Shan.

\begin{tabular}{lrrrrrrr}
\hline RG type & $\begin{array}{r}\text { Number of } \\
\text { landforms }\end{array}$ & $\begin{array}{r}\text { RG area } \\
\left(\mathrm{km}^{2}\right)\end{array}$ & $\begin{array}{c}\text { Altitude } \\
(\mathrm{m} \text { a.s.l. })\end{array}$ & $\begin{array}{c}\text { Length } \\
(\mathrm{m})\end{array}$ & $\begin{array}{c}\text { Width } \\
(\mathrm{m})\end{array}$ & $\begin{array}{c}\text { Gradient of } \\
\text { slope }\left({ }^{\circ}\right)\end{array}$ & $\begin{array}{c}\text { MAF } \\
(\mathrm{m} \text { a.s.l. })\end{array}$ \\
\hline Moraine & 146 & 28.11 & 4501 & 793 & 235 & 28.45 & 4385 \\
Talus & 149 & 27.59 & 4442 & 805 & 228 & 30.05 & 4321 \\
Tongue & 279 & 52.87 & 4470 & 829 & 211 & 28.89 & 4347 \\
Lobate & 16 & 2.83 & 4491 & 275 & 582 & 35.69 & 4447 \\
MTRG & 139 & 26.86 & 4496 & 817 & 218 & 27.96 & 4377 \\
MLRG & 7 & 1.25 & 4592 & 303 & 564 & 38.29 & 4539 \\
TTRG & 140 & 26.01 & 4444 & 841 & 204 & 29.81 & 4317 \\
TLRG & 9 & 1.58 & 4412 & 253 & 595 & 33.67 & 4376 \\
All RG & 295 & 55.70 & 4471 & 799 & 231 & 29.26 & 4352 \\
\hline
\end{tabular}

Note: RG is rock glaciers, MTRG is moraine-type and tongue-shaped rock glaciers, MLRG is moraine-type and lobate rock glaciers, TTRG is talus-derived and tongue-shaped rock glaciers, TLRG is talus-derived and lobate rock glaciers, and MAF is minimum altitude of rock glacier front. Altitude of rock glacier, altitude of rock glacier front, length, width, and gradient of slope are all mean values.

\section{Results}

In total, 295 rock glaciers were identified in Daxue Shan (Fig. 3), covering an area of $55.70 \mathrm{~km}^{2}$ (Table 2). Of these, $50.51 \%$ were talus-derived rock glaciers, the other $49.49 \%$ were moraine-type rock glaciers. Most $(94.58 \%)$ of the rock glaciers were tongue-shaped and the rest were lobate-shaped.

The rock glaciers are concentrated at altitudes between 4300 and $4600 \mathrm{~m}$ a.s.l., with a mean altitude of $4471 \mathrm{~m}$ a.s.l. (Fig. 4a). Moraine-type rock glaciers are mainly concentrated between 4400 and $4600 \mathrm{~m}$ a.s.l., and talus-derived rock glaciers between 4300 and $4550 \mathrm{~m}$ a.s.l. In terms of general morphology, both tongue-shaped and lobate-shaped rock glaciers are mainly located between 4350 and $4600 \mathrm{~m}$ a.s.1. (Fig. 4a). The upper boundaries for the vast majority of rock glacier types were $\sim 4600 \mathrm{~m}$ a.s.l., because at higher altitudes there are often ice glaciers. Figure $4 \mathrm{~b}$ shows the ranges in areas covered by different types of rock glaciers. Apart from a few outliers, the area of most rock glacier types area is $<0.3 \mathrm{~km}^{2}$, and in this regard there is no clear difference between rock glacier types. Figure $4 \mathrm{c}$ shows the ranges in the mean gradients of the slopes of different types of rock glaciers. Moraine-type and talus-derived rock glaciers exhibit mean gradients that are concentrated within the $22-$ $35^{\circ}$ range. However, tongue-shaped and lobate-shaped rock glaciers display a difference in mean gradient. Tongueshaped rock glaciers have slopes with mean gradients which are concentrated in the $22-35^{\circ}$ range, whereas those of lobate rock glaciers fall within the $27-45^{\circ}$ range. This means that the upper $\left(\sim 10^{\circ}\right)$ and lower $\left(\sim 5^{\circ}\right)$ slopes of tongueshaped rock glaciers are both shallower than for lobate rock glaciers. Figure $4 \mathrm{~d}$ displays the ranges in the lengths of different types of rock glaciers. Moraine-type and talus-type rock glaciers have similar lengths $(500-1000 \mathrm{~m})$, but when the rock glaciers are categorized by shape, tongue-shaped ones $(500-1000 \mathrm{~m})$ are generally longer than lobate-shaped rock glaciers $(200-400 \mathrm{~m})$.
Figure 5 shows rock glacier abundance vs. aspect. Our data set revealed that, apart from south-facing (5.44\%), south-east-facing $(3.06 \%)$, and north-east-facing $(20.75 \%)$ slopes, the rock glaciers are fairly evenly distributed on slopes with the remaining five aspects that each account for $\sim 15 \%$ of the total. Moraine-type rock glaciers are most often north-east-facing $(30.34 \%)$ or north-facing (20\%), whereas talus-derived rock glaciers are most often southwest-facing (22.82\%) or west-facing (17.45\%). Lobate rock glaciers tend to be rare on south-facing $(6.25 \%)$ and southeast-facing $(0 \%)$ slopes but are more commonly on northfacing, north-west-facing, and east-facing, with each aspect accounting for $\sim 18.75 \%$ of the total. We compared all our results and discovered that shady (i.e. N, NE, and E) slopes have more moraine-type rock glaciers, and sunny (i.e. W, $\mathrm{SW}$, and S) slopes have more derived from talus. Northfacing (i.e. N, NW, and NE) slopes also seem to be more favourable for the formation of lobate rock glaciers than do south-facing (i.e. SW, S, and SE) ones (Fig. 5), possibly in relation to the abundance of debris-producing steep rock walls on north faces. In contrast to other regions (Lilleøren and Etzelmüller, 2016; Onaca et al., 2017), we found that in Daxue Shan both moraine-type and talus-derived rock glaciers have developed in the monzogranitic areas, and that rock glaciers and monzonitic granite exhibit a high spatial correlation and interdependence (Fig. 6).

Table 3 shows the results of the correlation analysis. Positive correlations between rock glacier latitude, altitude, and length, and a negative correlation between altitude and mean slope were significant ( $p$ value $\leq 0.05$ ). Negative correlations between latitude and longitude, longitude and altitude, length and mean slope, and area and mean slope, and positive correlations of area with length and width were highly significant ( $p$ value $\leq 0.01$ ) 
(a)

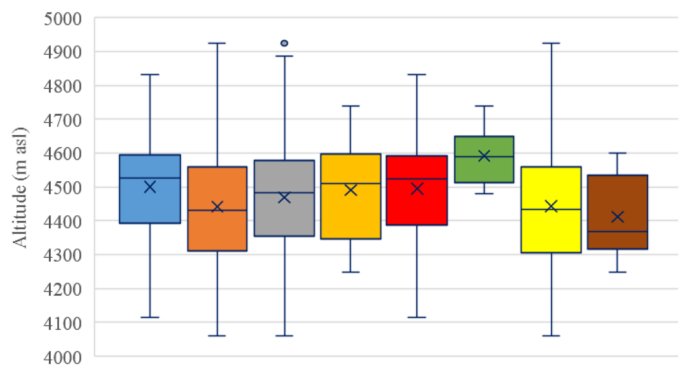

(c)

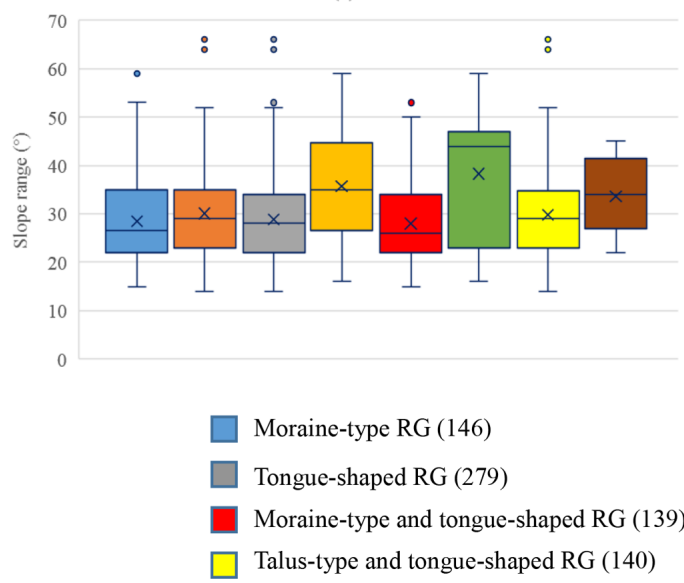

(b)

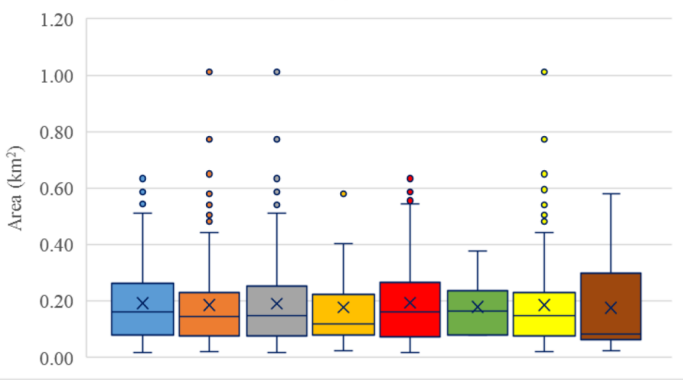

(d)

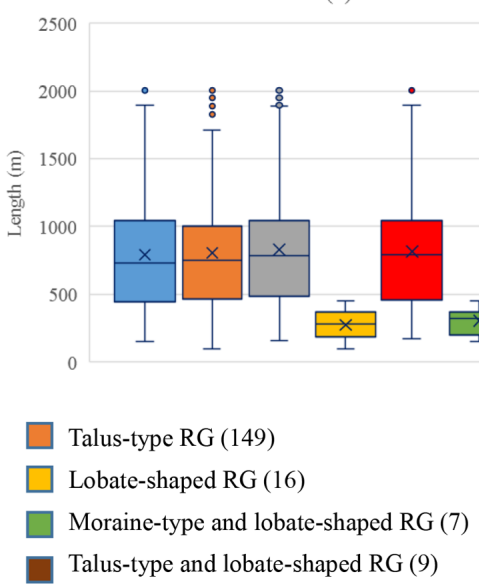

Figure 4. Box plots illustrating the distributional characteristics of rock glaciers in Daxue Shan: (a) average altitude ( $\mathrm{m}$ a.s.1.), (b) area $\left(\mathrm{km}^{2}\right)$, (c) range in the gradient of the slope $\left(^{\circ}\right)$, and (d) length $(\mathrm{m})$. Box plots represent $25-75 \%$ of all values, the caps at the ends of the vertical lines represent $10-90 \%$ of values, and the line in the centre of each box indicates the median value. The numbers of each rock glacier type are in brackets in the legend.

\section{Discussion}

The spatial distribution and dynamics of rock glaciers are especially dependent on the local topography and climate (Springman et al., 2012; Delaloye et al., 2013). Lithology also exerts considerable control on the rock glaciers (Onaca et al., 2017). Analysing local environmental factors (i.e. climatic, topographical, and lithological factors) is therefore crucial to obtaining an understanding of the formation, development, and spatial distribution of rock glaciers.

\subsection{Topographical controls on rock glaciers}

The significantly positive correlations between rock glacier latitude, altitude, and length (Table 3) are locally determined by the topographical characteristics. With an increase in latitude from the south to the north, the high-altitude rock glaciers increase in number, and flow further downvalley than those at low altitude. The altitudes of the mountains and rock glacier lengths increase with latitude, whereas air temperatures decrease, which implies that the northern sector of Daxue Shan has an environment that is more conducive to the formation of rock glaciers and other periglacial land- forms. Likewise, the significantly negative correlation between latitude and longitude (Table 3) indicates that local environmental factors dominantly control rock glacier distribution despite a general increase in relief in the northeast of the Daxue Shan region compared to the south-west (Fig. 3a). There is also a significantly negative correlation between longitude and altitude (Table 3), as lower altitude areas to the east are less conducive to the development of rock glaciers where warmer and more humid conditions are common. The negative correlation that exists between rock glacier length and mean gradient of slope is likely because the shortest rock glaciers are the talus-derived variety, and these have usually developed in steep topographical environments. Rock glacier area and mean gradient of slope, and altitude and mean slope are significantly negatively correlated (Table 3), likely because larger and high-altitude rock glaciers are mostly concentrated on gentle slopes that may be more conducive to their development. In summary, the topography of Daxue Shan is an important environmental control on the formation, development, and spatial distribution of the region's rock glaciers. 

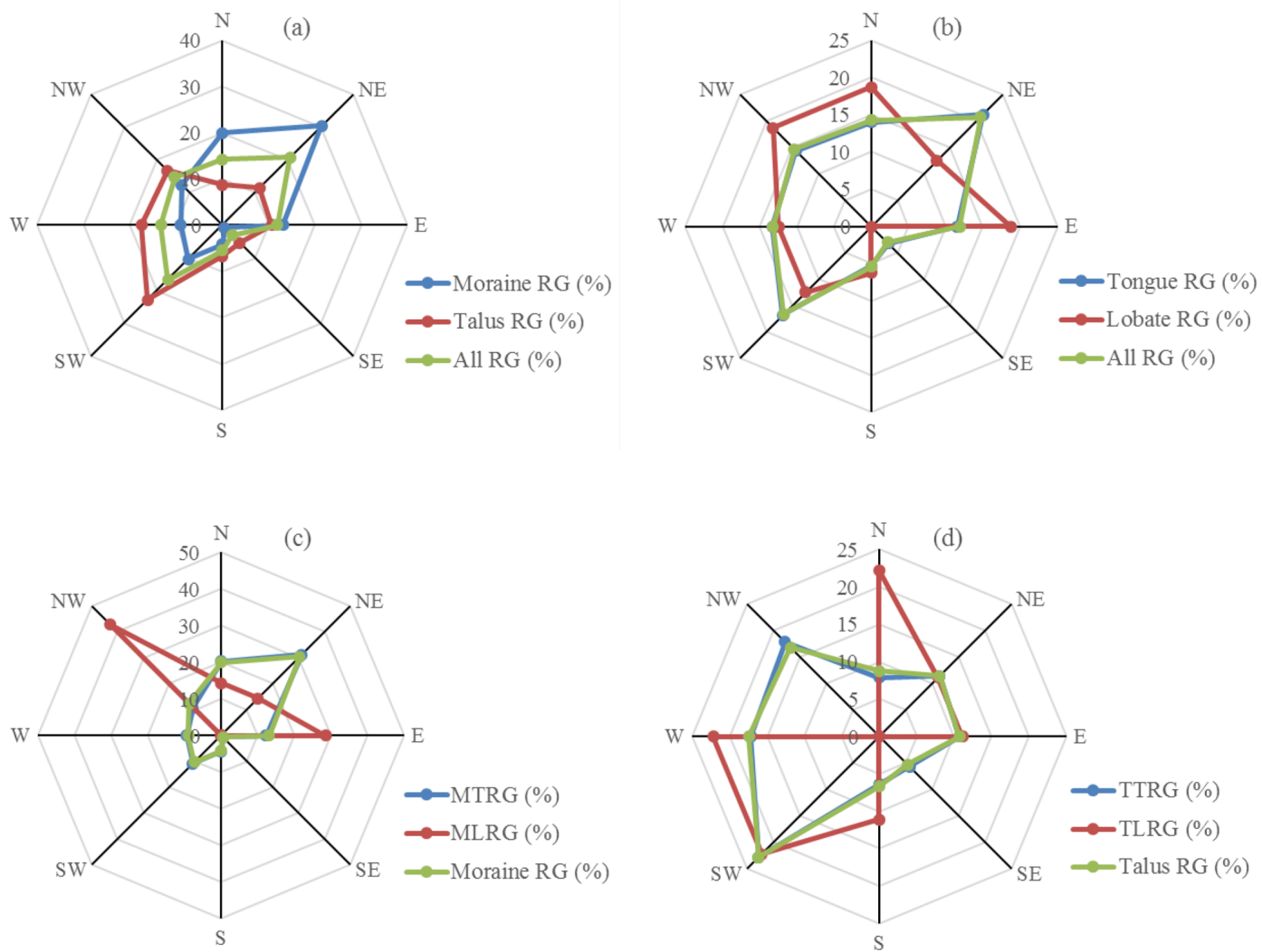

Figure 5. Analysis of the abundances of different rock glacier types vs. aspect. The number of rock glaciers for each aspect on each of the four radar plots is shown as a percentage (\%). Note: RG is rock glaciers, MTRG is moraine-type and tongue-shaped rock glaciers, MLRG is moraine-type and lobate rock glaciers, TTRG is talus-derived and tongue-shaped rock glaciers, and TLRG is talus-derived and lobate rock glaciers.

Table 3. Correlation matrix of rock glacier variables.

\begin{tabular}{lrrrrrrrr}
\hline & Latitude & Longitude & Altitude & Length & Width & RG area & Mean slope & Aspect \\
\hline Latitude & 1.000 & & & & & & & \\
Longitude & $-\mathbf{0 . 8 9 3} * *$ & 1.000 & & & & & & \\
Altitude & $\mathbf{0 . 1 1 6}^{*}$ & $-\mathbf{0 . 2 9 0}$ & 1.000 & & & & & \\
Length & $\mathbf{0 . 1 0 2}^{* *}$ & -0.062 & -0.075 & 1.000 & & & & \\
Width & -0.020 & 0.025 & 0.087 & 0.063 & 1.000 & & \\
RG area & 0.029 & 0.002 & 0.031 & $\mathbf{0 . 7 7 6}^{* *}$ & $\mathbf{0 . 5 7 2}^{* *}$ & 1.000 & \\
Mean slope & 0.092 & -0.004 & $-\mathbf{0 . 1 0 2}^{*}$ & $-\mathbf{0 . 3 4 1}^{* *}$ & -0.004 & $-\mathbf{0 . 2 6 5}^{* *}$ & 1.000 & \\
Aspect & -0.016 & -0.034 & 0.045 & 0.013 & -0.026 & 0.010 & -0.068 & 1.000 \\
\hline
\end{tabular}

Note: correlations in bold are significant. ${ }^{*}$ indicates a $p$ value $\leq 0.05 .{ }^{* *}$ indicates a $p$ value $\leq 0.01$.

The mean altitude of a rock glacier's front (MAF) has often been taken to be a good approximation of the lower boundary of the discontinuous permafrost zone (i.e. Scotti et al., 2013). We found a substantial altitudinal difference between the lower permafrost boundaries identified on the above-mentioned eight aspects. For example, permafrost was assumed to be probable above $4300 \mathrm{~m}$ a.s.l. on east-facing slopes, and above $4403 \mathrm{~m}$ a.s.l. on west-facing slopes. The mean lower permafrost boundary was calculated as occurring at $4352 \mathrm{~m}$ a.s.l. (derived from a mean value of $4315 \mathrm{~m}$ a.s.l. for east-facing slopes, and $4419 \mathrm{~m}$ a.s.l. for west-facing slopes). The mean lower permafrost boundary on east-facing (shady) slopes would therefore be $\sim 104 \mathrm{~m}$ lower than that of west-facing (sunny) slopes (Fig. 7).

In addition, the formation and development of the Daxue Shan rock glaciers are also strongly influenced by the landforms created by glacial erosion and deposition. The southeastern margins of the TP are in a region of Quaternary 


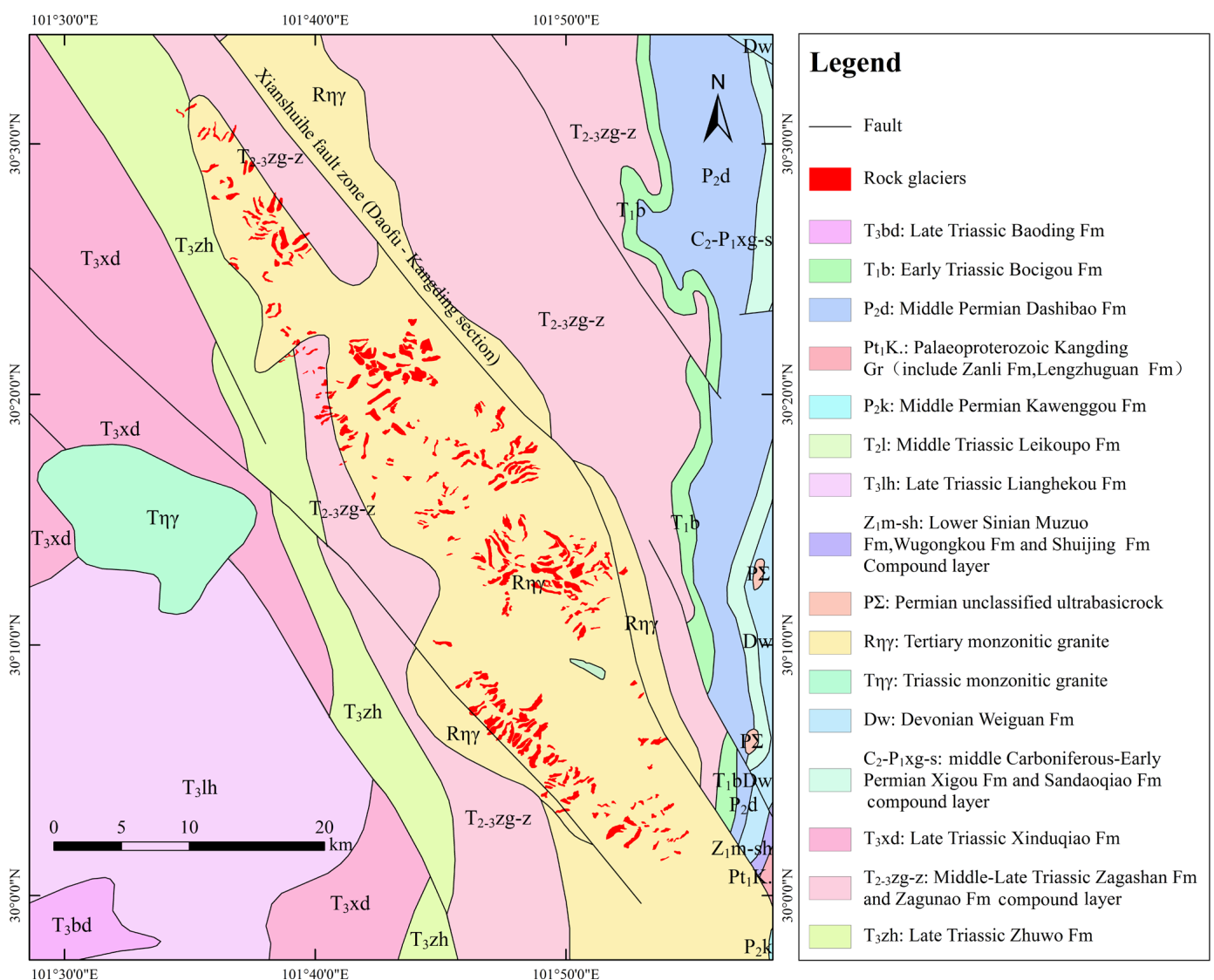

Figure 6. The rock glaciers of Daxue Shan superimposed on the local lithologic-geologic environment. Stratigraphic data from Li et al. (1999).

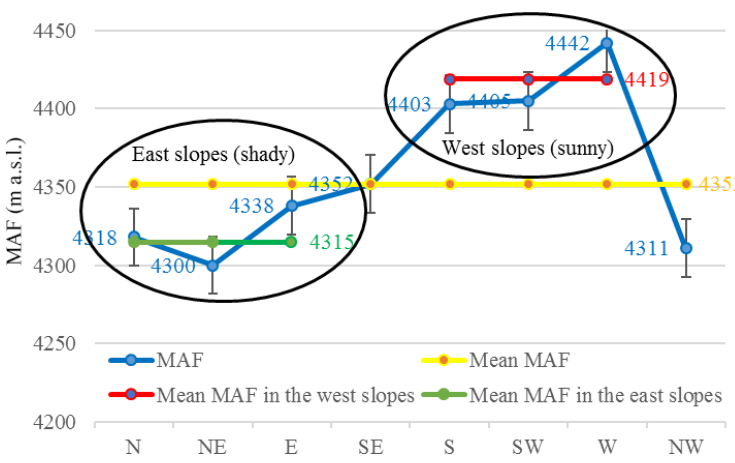

Figure 7. Minimum altitudinal rock glacier fronts (MAF) for all eight aspects, along with the overall mean. These values are taken to represent the lower boundaries of the potential permafrost extent in the Daxue Shan region (bars indicate standard errors of the mean). Daxue Shan lies along an approximately NW-SE axis; therefore we used this as the boundary separating east-facing (i.e. N, NE, E) shady slopes from west-facing (i.e. S, SW, W) sunny slopes.

glaciation which has been, and continues to be, strongly affected by monsoonal atmospheric circulations (Owen et al., 2005). This region possesses numerous ancient glacial relics and abundant landforms created by glacial erosion and deposition ( $\mathrm{Li}$ and Yao, 1987). We found that the distribution of rock glaciers is in close association with ice glaciers, as the upper boundaries for rock glaciers were $\sim 4600 \mathrm{~m}$ a.s.l., and at higher altitude there are often ice glaciers. In the context of global warming, it is widely accepted that the majority of glaciers on the Tibetan Plateau (TP) and its surroundings have experienced accelerated reduction (Bolch et al., 2012; Yao et al., 2012). The rate of glacier decline in Daxue Shan was $-0.25 \pm 0.20 \%$ year $^{-1}$ during 1990-2014 (Wang et al., 2017a), with some ice glaciers transforming to rock glaciers. Glacial depositional landforms (e.g. moraine ridges) are highly conducive to the formation and development of moraine-type rock glaciers. Moraine ridges or moraines left after the retreat of the ancient glaciers can provide significant quantities of boulders, erratic blocks, debris, sand, and ground ice. In the process of downslope movement, rock glaciers can incorporate old moraine material as well as the debris from both sides of the moraine ridge. Glacial erosional landforms in particular have a close relation with the formation and development of talus-derived rock glaciers. Ice structures, snow layers, and moraines within glaciers collapse from time to time, supplying talus to the feet of moun- 
(a) Kangding (2615.7 m a.s.l.)

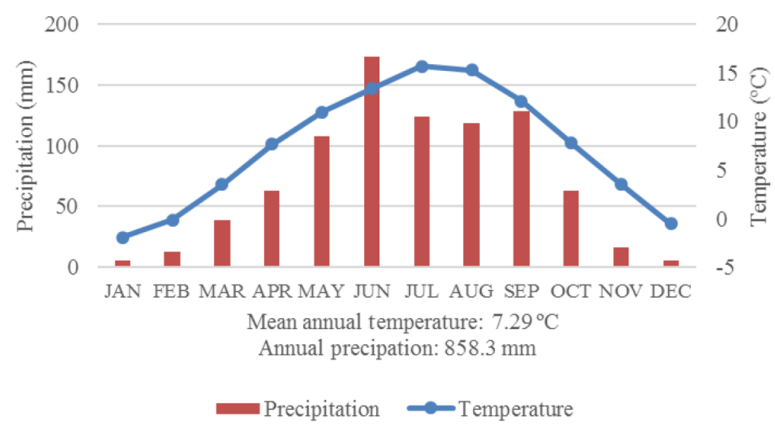

(c) Danba (1949.7 m a.s.1.)

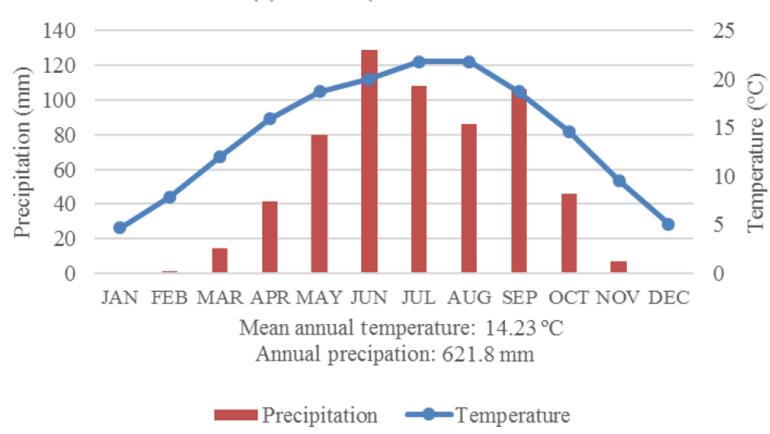

(b) Daofu (2957.2 m a.s.1.)

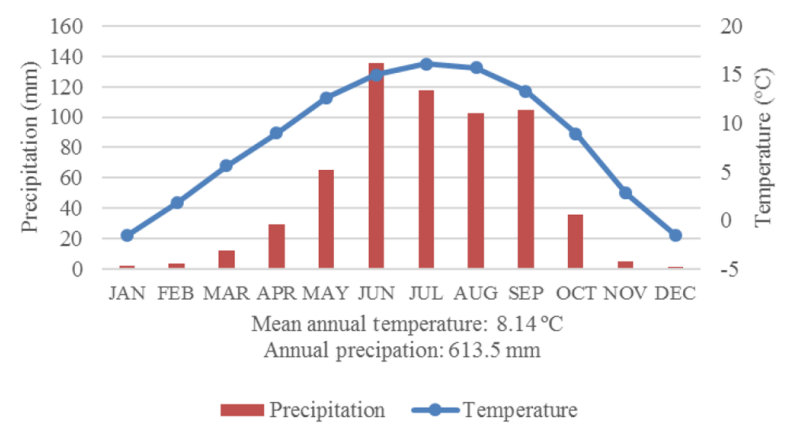

(d) Ganzi (3393.5 m a.s.1.)

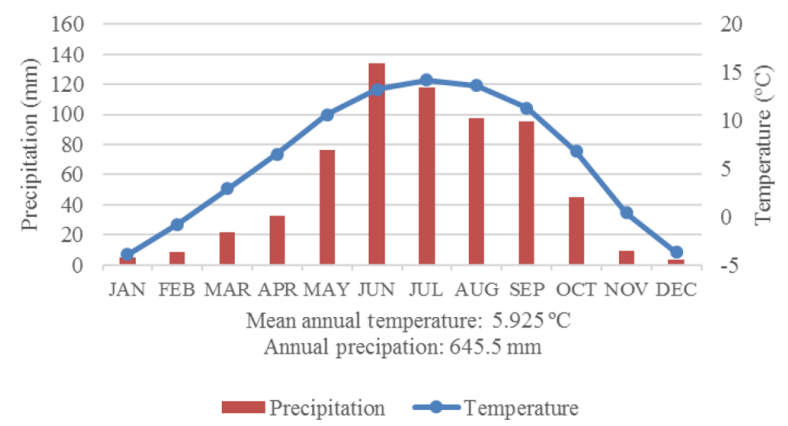

Figure 8. Climatographs for the (a) Kangding (2615.7 ma.s.1., $\left.30.03^{\circ} \mathrm{N}, 101.58^{\circ} \mathrm{E}\right)$, (b) Daofu $\left(2957.2 \mathrm{ma.s} .1 ., 30.59^{\circ} \mathrm{N}, 101.07^{\circ} \mathrm{E}\right)$, (c) Danba (1949.7 m a.s.1., $\left.30.53^{\circ} \mathrm{N}, 101.53^{\circ} \mathrm{E}\right)$, and (d) Ganzi $\left(3393.5 \mathrm{~m}\right.$ a.s.1., $\left.31.37^{\circ} \mathrm{N}, 100^{\circ} \mathrm{E}\right)$ meteorological stations. Data sources: Meteorological Data Centre of the China Meteorological Administration (http://data.cma.cn/, last access: 2 June 2017, calculated for the period 1981-2010).

tains. As a result of the freeze-thaw process and the effect of gravity, talus creep then forms rock glaciers.

\subsection{Climatic controls on rock glaciers}

The west-facing slopes of Daxue Shan lie in the intersection between a sub-frigid monsoonal zone and a continental plateau climatic zone and therefore experience a cold-temperate climate. At the Daofu meteorological station (2957.2 $\mathrm{m}$ a.s.1.), mean annual precipitation (MAP) is $\sim 613.5 \mathrm{~mm}$, and mean annual temperature (MAT) is $\sim 8.14^{\circ} \mathrm{C}$ (Fig. 8b). Based on an adiabatic rate of $0.65^{\circ} \mathrm{C} / 100 \mathrm{~m}$, we estimated the MAT at $4311 \mathrm{~m}$ a.s.l. (i.e. the lower permafrost boundary) to be $\sim-0.66^{\circ} \mathrm{C}$. The eastfacing slopes of Daxue Shan are principally affected by a subtropical monsoonal climatic environment and by a southwesterly monsoonal atmospheric circulation but also by a south-westerly monsoonal atmospheric circulation. Eastfacing slopes therefore experience high levels of precipitation (snowfall). MAP at the Kangding meteorological station (2615.7 ma.s.1.) reaches $858.3 \mathrm{~mm}$, and MAT is $\sim 7.29^{\circ} \mathrm{C}$ (Fig. 8a). We calculated the MAT at $4352 \mathrm{~m}$ a.s.l. (i.e. the lower permafrost boundary) to be $\sim-4.00^{\circ} \mathrm{C}$. Here, the freeze-thaw process would be frequent (Fig. 8), meaning that the climatic environment would provide temperature and precipitation conditions that are highly favourable to the formation and development of rock glaciers.

The distribution of rock glaciers in Daxue Shan is in general agreement with Gruber's (2012) global Permafrost Zonation Index (PZI) map, but many rock glaciers are situated within the PZI fringe of uncertainty (Fig. 3b). However, the PZI is strictly controlled by temperature that decreases with increasing altitude; thus our results indicate the importance of the local climatic controls on development of rock glaciers and thus permafrost. In addition, compared with the distribution of ice glaciers in Daxue Shan, the distribution of rock glaciers also has characteristic small differences between the south and north, owing to a north-south corridor effect for water and heat transport and diffusion through the longitudinal gorges (Wang et al., 2017a).

\subsection{Lithological controls on rock glaciers}

Lithology is a critical control for the supply of talus to ice and rock glacier surfaces (Haeberli et al., 2006). Figure 6 shows that the major exposed strata in the Daxue Shan region are composed of Tertiary monzonitic granite, consistent with the NW-SE trending Xianshuihe Fault. The surrounding moun- 
tains in this area generally consist of biotite-muscovite granite that intruded 16-13 Ma ago (Roger et al., 1995). Also located in this region is the tectonically important Zheduotang Fault, which runs through the Zheduo Valley, and is one of the most active fault systems on the TP's margins (Allen et al., 1991). It can be seen from Fig. 6 that the distribution of rock masses along the Xianshuihe Fault in the Daxue Shan region is clearly controlled by this NW-SE left-lateral strikeslip fault.

The Tertiary monzogranites are clearly highly conducive to the formation and development of rock glaciers. This is consistent with the findings of Onaca et al. (2017) in the southern Carpathian Mountains. According to Popescu et al. (2015), rock glaciers located in granitic and granodioritic massifs are composed of larger clasts compared with those found in metamorphic massifs. Thus, the higher porosity of the substrata in granitic and granodioritic massifs allows for significant cooling beneath the bouldery mantle because the denser cold air is trapped between the large boulders (Balch, 1900). The lithological and mineralogical characteristics which accompany the high porosity of tertiary monzogranites are therefore more favourable to the formation and development of local rock glaciers than are other lithologies. In addition, rock glacier formation is also controlled by slope and sedimentation rates contributing debris to the landforms (Müller et al., 2016). There are large sources of sediment and sediment storages in Daxue Shan, which are controlled by the processes occurring within this setting (Müller et al., 2014). An abundance of steep rock walls and deepened valley sides provides catchment areas for rock glacier development and, when combined with intense monsoonal precipitation and tectonic activity, drives sediment transport processes and rock glacier development in Daxue Shan.

Several researchers (e.g. Cui and Zhu, 1989; Zhu, 1992; Zhu et al., 1992; Liu et al., 1995; Bolch and Gorbunov, 2014) have previously identified hundreds of rock glaciers in the northern Tian Shan Mountains. They found that most of the identified rock glaciers were tongue-shaped and were located at altitudes between 3300 and $3900 \mathrm{~m}$ a.s.l. on north-facing slopes. Most rock glaciers in Daxue Shan are also tongueshaped. However, the altitudes at and the aspects on which these rock glaciers are found to differ between the Daxue and the Tian Shan mountain ranges. First, in terms of altitude, the rock glaciers of Daxue Shan are located between 4300 and $4600 \mathrm{~m}$ a.s.1., which is higher than the Tian Shan rock glaciers by approximately $700-1000 \mathrm{~m}$. It would be reasonable to assume, therefore, that the rock glaciers located in lower latitudes are more likely to be found at higher altitudes. Second, in terms of aspect, the rock glaciers of Daxue Shan are more evenly distributed across all eight above-mentioned aspects than are the rock glaciers of the Tian Shan Mountains. This could be explained by several factors, including the differences in overall altitude as well as the orientation of the main massif of each mountain range. Daxue Shan lies along an approximately NW-SE axis, whereas the Tian Shan
Mountains are roughly W-E in orientation. Rock glaciers are therefore less commonly found on the east- and westfacing slopes of the Tian Shan. The effect of solar radiation is stronger on the south-facing slopes of the Tian Shan Mountains than on its north-facing ones, meaning that conditions on these south-facing slopes are less conducive to the development of rock glaciers; most of the range's rock glaciers are therefore found on its north-facing slopes. Furthermore, when higher altitudes are reached, all aspects experience lower air temperatures, resulting in a lessening of the impact caused by the difference between air temperature and solar radiation exposure; this phenomenon is similar to that found in Daxue Shan and explains why rock glaciers there are fairly evenly distributed on all eight aspects. However, when altitudes are lower, the impact of solar radiation combined with warmer air temperatures is greater, particularly on south-facing slopes; both temperature and solar radiation are lower on shady north-facing slopes, however, explaining the predominance of north-facing rock glaciers in the Tian Shan Mountains.

\section{Conclusions}

Rock glaciers are widespread in Daxue Shan, and of these, tongue-shaped rock glaciers cover the largest area. The occurrence and characteristics of these rock glaciers can mostly be explained by local environmental controls (i.e. climatic, topographical, and lithological factors).

In total, 295 rock glaciers were identified in Daxue Shan, covering a total area of $55.70 \mathrm{~km}^{2}$. The altitudes at which moraine-type rock glaciers are found (i.e. 4400$4600 \mathrm{~m}$ a.s.1.) are at least $50-100 \mathrm{~m}$ higher than for talusderived rock glaciers (i.e. $4300-4550 \mathrm{~m}$ a.s.1.), although the upper altitudinal limit for both these types of rock glacier is $\sim 4600 \mathrm{~m}$ a.s.1. At higher altitudes there are often ice glaciers. Except for a few outliers, the area of each type of rock glacier is no greater than $0.3 \mathrm{~km}^{2}$. There is no significant difference between moraine-type and talus-derived rock glaciers in terms of the mean slope gradients (i.e. they are all clustered within the $22-35^{\circ}$ range), but the upper and lower mean slope gradients of tongue-shaped rock glaciers are $\sim 10$ and $\sim 5^{\circ}$ lower than for lobate rock glaciers, respectively. In terms of length, moraine- and talus-derived rock glaciers have similar lengths $(\sim 500-1000 \mathrm{~m})$, but according to shape, lobate-shaped rock glaciers are distinctly shorter than tongue-shaped by $\sim 300-600 \mathrm{~m}$. We found shady (i.e. $\mathrm{N}$, NE, and E) slopes more conducive to the presence of moraine-type rock glaciers than sunny (i.e. W, SW, and S) ones that appear more conducive to the presence of talusderived rock glaciers. In addition, north-facing (i.e. N, NW, and NE) slopes appeared more favourable to the formation of lobate rock glaciers than south-facing ones (i.e. SW, S, and SE). The mean regional lowest altitudinal limit of rock glaciers is $4352 \mathrm{~m}$ a.s.l., an altitude which was taken to in- 
dicate the local permafrost's mean lower boundary. On eastfacing slopes, the permafrost's lower boundary can therefore reasonably be assumed to be $\sim 104 \mathrm{~m}$ lower than on westfacing slopes.

The correlation matrix of rock glacier variables indicates that the formation of rock glaciers is closely related to local environmental conditions. The local climatic environment leads to a frequent freeze-thaw process within these rock glaciers, a process which is also beneficial to their formation and development. Tertiary monzonitic granite, with its large clastic and highly porous characteristics, is more sensitive than other lithological components to the freezethaw process, and continuous weathering of this monzogranite substratum thus provides the ideal raw material for the rock glaciers of Daxue Shan.

Data availability. The data associated with this article can be found in the Supplement. These data include maps of the most important areas described in this article, as well as a tabulation of the parameters of the rock glaciers found in Daxue Shan.

Supplement. The supplement related to this article is available online at: https://doi.org/10.5194/tc-12-2327-2018-supplement.

Author contributions. ZR and GL designed the research. ZR performed the analysis and wrote the paper.

Competing interests. The authors declare that they have no conflict of interest.

Acknowledgements. This work was funded by the National Natural Science Foundation of China (grant nos. 41230743 and 41371082). We thank the editor and three reviewers for detailed and constructive suggestions for revisions to the manuscript.

Edited by: Peter Morse

Reviewed by: Tobias Bolch, Luke Copland, and Johann Müller

\section{References}

Allen, C. R., Luo, Z. L., Qian, H., Wen, X. Z., Zhou, H. W., and Huang, W. S.: Field study of a highly active fault zone: The Xianshuihe fault of southwestern China, Geol. Soc. Am. Bull., 103, 1178-1199, https://doi.org/10.1130/00167606(1991)103<1178:FSOAHA > 2.3.CO;2, 1991.

Allen, S. K., Owens, I., and Huggel, C.: A first estimate of mountain permafrost distribution in the Mount Cook region of New Zealand's southern alps, 9th International Conference on Permafrost, Fairbanks, Alaska, 29 June-3 July 2008, 37-42, 2008.

Azócar, G. F. and Brenning, A.: Hydrological and geomorphological significance of rock glaciers in the Dry An- des, Chile $\left(27^{\circ}-33^{\circ} \mathrm{S}\right)$, Permafrost Periglac., 21, 42-53, https://doi.org/10.1002/ppp.669, 2010.

Balch, E. S.: Glacières or Freezing Caverns, Allen, Lane \& Scott, Philadelphia, 140 pp., 1900.

Barsch, D.: Rockglaciers: Indicators for the Present and Former Geoecology in High Mountain Environments, Springer-Verlag, Berlin, 331 pp., 1996.

Berthling, I.: Beyond confusion: Rock glaciers as cryoconditioned landforms, Geomorphology, 131, 98-106, https://doi.org/10.1016/j.geomorph.2011.05.002, 2011.

Boeckli, L., Brenning, A., Gruber, S., and Noetzli, J.: A statistical approach to modelling permafrost distribution in the European Alps or similar mountain ranges, The Cryosphere, 6, 125-140, https://doi.org/10.5194/tc-6-125-2012, 2012.

Bolch, T.: Using ASTER and SRTM DEMs for studying glaciers and rock glaciers in northern Tien Shan, in: Proceedings Part I of the Conference "Theoretical and applied problems of geography on a boundary of centuries", Almaty, Kasakhstan, 254-258, 2004.

Bolch, T. and Gorbunov, A. P.: Characteristics and Origin of Rock Glaciers in Northern Tien Shan (Kazakhstan/Kyrgyzstan), Permafrost Periglac., 25, 320-332, https://doi.org/10.1002/ppp.1825, 2014.

Bolch, T., Kulkarni, A., Kaab, A., Huggel, C., Paul, F., Cogley, J. G., Frey, H., Kargel, J. S., Fujita, K., Scheel, M., Bajracharya, S., and Stoffel, M.: The state and fate of Himalayan glaciers, Science, 336, 310-314, https://doi.org/10.1126/science.1215828, 2012.

Bolch, T. and Marchenko, S.: Significance of glaciers, rockglaciers and ice-rich permafrost in the Northern Tien Shan as water towers under climate change conditions, in: Selected Papers from the Workshop "Assessment of Snow, Glacier and Water Resources in Asia”, Almaty, Kazakhstan, 28-30 November 2006, edited by: Braun, L., Hagg, W., Severskiy, I. V., and Young, G. J., IHP/HWRP-Berichte 8, 132-144, https://doi.org/10.5167/uzh137250, 2009.

Brazier, V., Kirkbride, M. P., and Owens, I. F.: The relationship between climate and rock glacier distribution in the Ben Ohau Range, New Zealand, Geogr. Ann. A, 80, 193-207, https://doi.org/10.1111/j.0435-3676.1998.00037.x, 1998.

Brenning, A.: Geomorphological, hydrological and climatic significance of rock glaciers in the Andes of Central Chile $\left(33-35^{\circ} \mathrm{S}\right)$, Permafrost Periglac., 16, 231-240, https://doi.org/10.1002/ppp.528, 2005.

Brenning, A.: Benchmarking classifiers to optimally integrate terrain analysis and multispectral remote sensing in automatic rock glacier detection, Remote Sens. Environ., 113, 239-247, https://doi.org/10.1016/j.rse.2008.09.005, 2009.

Capps, S. R.: Rock glaciers in Alaska, J. Geology, 18, 359-375, https://doi.org/10.1086/621746, 1910.

Chueca, J.: A Statistical Analysis of the Spatial Distribution of Rock Glaciers, Spanish Central Pyrenees, Permafrost Periglac., 3, 261-265, 1992.

Clark, D. H., Steig, E. J., Potter, N., and Gillespie, A. R.: Genetic variability of rock glaciers, Geogr. Ann. A, 80, 175-182, https://doi.org/10.1111/j.0435-3676.1998.00035.x, 1998.

Colucci, R. R., Boccali, C., Žebre, M., and Guglielmin, M.: Rock glaciers, protalus ramparts and pronival ramparts in the south-eastern Alps, Geomorphology, 269, 112-121, https://doi.org/10.1016/j.geomorph.2016.06.039, 2016. 
Cremonese, E., Gruber, S., Phillips, M., Pogliotti, P., Boeckli, L., Noetzli, J., Suter, C., Bodin, X., Crepaz, A., Kellerer-Pirklbauer, A., Lang, K., Letey, S., Mair, V., Morra di Cella, U., Ravanel, L., Scapozza, C., Seppi, R., and Zischg, A.: Brief Communication: "An inventory of permafrost evidence for the European Alps", The Cryosphere, 5, 651-657, https://doi.org/10.5194/tc5-651-2011, 2011.

Cui, Z. J. and Zhu, C.: The structure pattern of temperature and mechanism of the rock glaciers in Urumqi River region in Tien Shan, Chinese Sci. Bull., 34, 134-137, 1989 (in Chinese).

Delaloye, R., Morard, S., Barboux, C., Abbet, D., Gruber, V., Riedo, M., and Gachet, S.: Rapidly moving rock glaciers in Mattertal, in: Mattertal - ein Tal in Bewegung, edited by: Graf, C., Publikation zur Jahrestagung der Schweizerischen Geomorphologischen Gesellschaft, St. Niklaus, 21-31, 2013.

Falaschi, D., Castro, M., Masiokas, M., Tadono, T., and Ahumada, A. L.: Rock Glacier Inventory of the Valles Calchaquíes Region $\left(\sim 25^{\circ} \mathrm{S}\right)$, Salta, Argentina, Derived from ALOS Data, Permafrost Periglac., 25, 69-75, https://doi.org/10.1002/ppp.1801, 2014.

Giardino, J. R. and Vick, S. G.: Geologic engineering aspects of rock glaciers, Rock Glaciers, edited by: Giardino, J., Shroder, J., and Vitek, J., Allen and Unwin, London, 265-287, 1987.

Gruber, S.: Derivation and analysis of a high-resolution estimate of global permafrost zonation, The Cryosphere, 6, 221-233, https://doi.org/10.5194/tc-6-221-2012, 2012.

Guglielmin, M. and Smiraglia, C.: The rock glacier inventory of the Italian Alps, Proceedings Seventh International Conference on Permafrost, Yellowknife, Northwest Territories, Canada, Collect. Nord., vol. 57, edited by: Lewkowicz, A. G. and Allard, M., Cent. d'Etudes Nord., Univ. Laval, Laval, Quebec, Canada, 375-382, 1998.

Haeberli, W.: Creep of mountain permafrost: internal structure and flow of alpine rock glaciers, Mitteilungen Der Versuchsanstalt für Wasserbau, Hydrologie und Glaziologie an der ETH Zürich, 77, 5-142, 1985.

Haeberli, W., Hallet, B., Arenson, L., Elconin, R., Humlun, O., Kaab, A., Kaufmann, V., Ladanyi, B., Matsuoka, N., Springman, S., and Vonder Muhll, D.: Permafrost creep and rock glacier dynamics, Permafrost Periglac., 17, 189-214, https://doi.org/10.1002/ppp.561, 2006.

Humlum, O.: The geomorphic significance of rock glaciers: estimates of rock glacier debris volumes and headwall recession rates in West Greenland, Geomorphology, 35, 41-67, https://doi.org/10.1016/S0169-555x(00)00022-2, 2000.

Ikeda, A. and Matsuoka, N.: Degradation of talus-derived rock glaciers in the Upper Engadin, Swiss Alps, Permafrost Periglac., 13, 145-161, https://doi.org/10.1002/ppp.413, 2002.

Janke, J. R.: Colorado Front Range rock glaciers: Distribution and topographic characteristics, Arct. Antarct. Alp. Res., 39, 74-83, https://doi.org/10.1657/1523-0430(2007)39[74:Cfrrgd]2.0.Co;2, 2007.

Janke, J. R., Ng, S., and Bellisario, A.: An inventory and estimate of water stored in firn fields, glaciers, debriscovered glaciers, and rock glaciers in the Aconcagua River Basin, Chile, Geomorphology, 296, 142-152, https://doi.org/10.1016/j.geomorph.2017.09.002, 2017.

Johnson, B. G., Thackray, G. D., and Van Kirk, R.: The effect of topography, latitude, and lithology on rock glacier distribution in the Lemhi Range, central Idaho, USA, Geomorphology, 91, 38-50, https://doi.org/10.1016/j.geomorph.2007.01.023, 2007.

Jones, D. B., Harrison, S., Anderson, K., and Betts, R. A.: Mountain rock glaciers contain globally significant water stores, Sci. Rep., 8, 2834, https://doi.org/10.1038/s41598-018-21244-w, 2018a.

Jones, D. B., Harrison, S., Anderson, K., Selley, H. L., Wood, J. L., and Betts, R. A.: The distribution and hydrological significance of rock glaciers in the Nepalese Himalaya, Global Planet. Change, 160, 123-142, https://doi.org/10.1016/j.gloplacha.2017.11.005, 2018 b.

Kääb, A., Huggel, C., Fischer, L., Guex, S., Paul, F., Roer, I., Salzmann, N., Schlaefli, S., Schmutz, K., Schneider, D., Strozzi, T., and Weidmann, Y.: Remote sensing of glacier- and permafrostrelated hazards in high mountains: an overview, Nat. Hazards Earth Syst. Sci., 5, 527-554, https://doi.org/10.5194/nhess-5527-2005, 2005.

Kenner, R. and Magnusson, J.: Estimating the Effect of Different Influencing Factors on Rock Glacier Development in Two Regions in the Swiss Alps, Permafrost Periglac., 28, 195-208, https://doi.org/10.1002/ppp.1910, 2017.

Krainer, K. and Ribis, M.: A Rock Glacier Inventory of the Tyrolean Alps (Austria), Austrian J. Earth Sc., 105, 32-47, 2012.

Li, S. D. and Yao, H. Q.: Preliminary Study on the Rock Glaciers in the Gongga Mt. Area, J. Glaciol. Geocryol., 9, 55-60, 1987 (in Chinese).

Li, T. D., Pan, W. C., and Liu, S. H.: National 1:500000 Digital Geological Map Database (NGMDB) System of People's Republic of China, Geoscientific Data \& Discovery Publishing Center, 1999 (in Chinese).

Lilleøren, K. S. and Etzelmüller, B.: A regional inventory of rock glaciers and ice-cored moraines in norway, Geogr. Ann. A, 93, 175-191, https://doi.org/10.1111/j.1468-0459.2011.00430.x, 2016.

Liu, G. N., Xiong, H. G., Cui, Z. J., and Song, C. Q.: The morphological features and environmental condition of rock glaciers in Tianshan mountains, Scientia Geographica Sinica, 15, 226-233, 1995 (in Chinese).

Liu, L., Millar, C. I., Westfall, R. D., and Zebker, H. A.: Surface motion of active rock glaciers in the Sierra Nevada, California, USA: inventory and a case study using InSAR, The Cryosphere, 7, 1109-1119, https://doi.org/10.5194/tc-7-1109-2013, 2013.

Martin, H. E.: Rock glaciers, Part 1: rock glacier morphology, classification and distribution, Prog. Phys. Geogr., 11, 260-282, 1987.

Millar, C. I. and Westfall, R. D.: Rock glaciers and related periglacial landforms in the Sierra Nevada, CA, USA, inventory, distribution and climatic relationships, Quaternary Int., 188, 90104, https://doi.org/10.1016/j.quaint.2007.06.004, 2008.

Müller, J., Gärtner-Roer, I., Kenner, R., Thee, P., and Morche, D.: Sediment storage and transfer on a periglacial mountain slope (Corvatsch, Switzerland), Geomorphology, 218, 35-44, https://doi.org/10.1016/j.geomorph.2013.12.002, 2014.

Müller, J., Vieli, A., and Gärtner-Roer, I.: Rock glaciers on the run - understanding rock glacier landform evolution and recent changes from numerical flow modeling, The Cryosphere, 10, 2865-2886, https://doi.org/10.5194/tc-10-2865-2016, 2016.

Onaca, A., Ardelean, F., Urdea, P., and Magori, B.: Southern Carpathian rock glaciers: Inventory, distribution and envi- 
ronmental controlling factors, Geomorphology, 293, 391-404, https://doi.org/10.1016/j.geomorph.2016.03.032, 2017.

Onaca, A. L., Urdea, P., and Ardelean, A. C.: Internal Structure and Permafrost Characteristics of the Rock Glaciers of Southern Carpathians (Romania) Assessed by Geoelectrical Soundings and Thermal Monitoring, Geogr. Ann. A, 95, 249-266, https://doi.org/10.1111/geoa.12014, 2013.

Owen, L. A., Finkel, R. C., Barnard, P. L., Haizhou, M., Asahi, K., Caffee, M. W., and Derbyshire, E.: Climatic and topographic controls on the style and timing of Late Quaternary glaciation throughout Tibet and the Himalaya defined by ${ }^{10} \mathrm{Be}$ cosmogenic radionuclide surface exposure dating, Quaternary Sci. Rev., 24, 1391-1411, https://doi.org/10.1016/j.quascirev.2004.10.014, 2005.

Popescu, R., Vespremeanu-Stroe, A., Onaca, A., and Cruceru, N.: Permafrost research in the granitic massifs of Southern Carpathians (Parâng Mountains), Z. Geomorphol., 59, 1-20, https://doi.org/10.1127/0372-8854/2014/0145, 2015.

Qiu, G. Q.: Development condition of alpline permafrost in the Mt.Tianshan, J. Glaciol. Geocryol., 15, 96-102, 1993 (in Chinese).

Ran, Z.: Empirical Research on Economic Spatial Difference Based on ESDA - A Case Study on the Silk Road Economic Belt in the Northwest of China, Econ. Geogr., 37, 28-34, https://doi.org/10.15957/j.cnki.jjdl.2017.05.004, 2017 (in Chinese).

Rangecroft, S., Harrison, S., Anderson, K., Magrath, J., Castel, A. P., and Pacheco, P.: A First Rock Glacier Inventory for the Bolivian Andes, Permafrost Periglac., 25, 333-343, https://doi.org/10.1002/ppp.1816, 2014.

Roer, I. and Nyenhuis, M.: Rockglacier activity studies on a regional scale: comparison of geomorphological mapping and photogrammetric monitoring, Earth Surf. Proc. Land., 32, 17471758, https://doi.org/10.1002/esp.1496, 2007.

Roger, F., Calassou, S., Lancelot, J., Malavieille, J., Mattauer, M., Xu, Z. Q., Hao, Z. W., and Hou, L. W.: Miocene emplacement and deformation of the Konga Shan granite (Xianshui He fault zone, west Sichuan, China): Geodynamic implications, Earth Planet. Sc. Lett., 130, 201-216, https://doi.org/10.1016/0012821x(94)00252-T, 1995.

Sattler, K., Anderson, B., Mackintosh, A., Norton, K., and de Róiste, M.: Estimating Permafrost Distribution in the Maritime Southern Alps, New Zealand, Based on Climatic Conditions at Rock Glacier Sites, Front. Earth Sci., 4, 4, https://doi.org/10.3389/feart.2016.00004, 2016.

Schmid, M.-O., Baral, P., Gruber, S., Shahi, S., Shrestha, T., Stumm, D., and Wester, P.: Assessment of permafrost distribution maps in the Hindu Kush Himalayan region using rock glaciers mapped in Google Earth, The Cryosphere, 9, 20892099, https://doi.org/10.5194/tc-9-2089-2015, 2015.

Scotti, R., Brardinoni, F., Alberti, S., Frattini, P., and Crosta, G. B.: A regional inventory of rock glaciers and protalus ramparts in the central Italian Alps, Geomorphology, 186, 136-149, https://doi.org/10.1016/j.geomorph.2012.12.028, 2013.
Slaymaker, O.: The role of remote sensing in geomorphology and terrain analysis in the Canadian Cordillera, Int. J. Appl. Earth Obs., 3, 11-17, https://doi.org/10.1016/s0303-2434(01)85016-9, 2001.

Springman, S. M., Arenson, L. U., Yamamoto, Y., Maurer, H., Kos, A., Buchli, T., and Derungs, G.: Multidisciplinary investigations on three rock glaciers in the Swiss Alps: legacies and future perspectives, Geogr. Ann. A, 94, 215-243, https://doi.org/10.1111/j.1468-0459.2012.00464.x, 2012.

Wahrhaftig, C. and Cox, A.: Rock Glaciers in the Alaska Range, Geol. Soc. Am. Bull., 70, 383-436, https://doi.org/10.1130/00167606(1959)70[383:Rgitar]2.0.Co;2, 1959.

Wang, X., Chai, K. G., Liu, S. Y., Wei, J. F., Jiang, Z. L., and Liu, Q. H.: Changes of glaciers and glacial lakes implying corridor-barrier effects and climate change in the Hengduan Shan, southeastern Tibetan Plateau, J. Glaciol., 63, 535-542, https://doi.org/10.1017/jog.2017.14, 2017a.

Wang, X., Liu, L., Zhao, L., Wu, T., Li, Z., and Liu, G.: Mapping and inventorying active rock glaciers in the northern Tien Shan of China using satellite SAR interferometry, The Cryosphere, 11, 997-1014, https://doi.org/10.5194/tc-11-997-2017, 2017 b.

White, A. and Copland, L.: Decadal-scale variations in glacier area changes across the Southern Patagonian Icefield since the 1970s, Arct. Antarct. Alp. Res., 47, 147-167, https://doi.org/10.1657/Aaar0013-102, 2015.

Yao, T. D., Thompson, L., Yang, W., Yu, W. S., Gao, Y., Guo, X. J., Yang, X. X., Duan, K. Q., Zhao, H. B., Xu, B. Q., Pu, J. C., Lu, A. X., Xiang, Y., Kattel, D. B., and Joswiak, D.: Different glacier status with atmospheric circulations in Tibetan Plateau and surroundings, Nat. Clim. Change, 2, 663-667, https://doi.org/10.1038/Nclimate1580, 2012.

Zhang, P. Z.: A review on active tectonics and deep crustal processes of the Western Sichuan region, eastern margin of the Tibetan Plateau, Tectonophysics, 584, 7-22, https://doi.org/10.1016/j.tecto.2012.02.021, 2013.

Zhang, Y. Z., Replumaz, A., Leloup, P. H., Wang, G. C., Bernet, M., van der Beek, P., Paquette, J. L., and Chevalier, M. L.: Cooling history of the Gongga batholith: Implications for the Xianshuihe Fault and Miocene kinematics of SE Tibet, Earth Planet. Sc. Lett., 465, 1-15, https://doi.org/10.1016/j.epsl.2017.02.025, 2017.

Zhu, C.: Some problems from the slope periglacio-landform on middle Tian Shan Mountain, Mountain Research, 10, 65-74, 1992 (in Chinese).

Zhu, C., Cui, Z. J., and Yao, Z.: Research on the feature of rock glaciers on the central Tian Shan Mountain, ACTA Geographica Sinica, 47, 233-241, 1992 (in Chinese).

Zhu, C., Zhang, J. X., and Cheng, P.: Rock glaciers in the Central Tianshan Mountains, China, Permafrost Periglac., 7, 69-78, 1996. 